\title{
STAG1 wt Allele
}

National Cancer Institute

\section{Source}

National Cancer Institute. STAG1 wt Allele. NCI Thesaurus. Code C131226.

Human STAG1 wild-type allele is located in the vicinity of 3q22.3 and is approximately 416

$\mathrm{kb}$ in length. This allele, which encodes cohesin subunit SA-1 protein, is involved in sister chromatid cohesion. 